\title{
Language Ideologies, Language Policies and their Translation into Fiscal Policies in the U.S. Perspectives of Language Education Community Stakeholders
}

\author{
Emre Başok ${ }^{1 *}$ \\ Peter Sayer ${ }^{1}$ \\ ${ }^{1}$ The Ohio State University \\ *Corresponding Author: basok.2@osu.edu \\ Received : 2020-SEP-16 \\ Accepted : 2020-NOV- 12
}

DOI: $10.46303 /$ jcve.2020.13

How to cite this paper: Başok, E., \& Sayer, P. (2020). Language Ideologies, Language Policies and their Translation into Fiscal Policies in the U.S. Perspectives of Language Education Community Stakeholders. Journal of Culture and Values in Education, 3(2), 54-80. doi.org/10.46303/jcve.2020.13

This is an Open Access article distributed under the terms of the Creative Commons Attribution 4.0 International license (https://creativecommons.org/licenses/by/4.0/)

\begin{abstract}
This study explored the potential effects of the Trump administration's proposed budget cuts through the lens of language ideologies in the language education community. This community includes English as a second language (ESL), dual language bilingual programs, and world/foreign language education. The Trump administration proposed cuts totaling \$4 billion by eliminating or reducing major language education programs. Through semistructured interviews, the researchers explored the perspectives of stakeholders who would be impacted. Six participants who are actively involved in the language education community at different levels including ESL, dual language bilingual, and world language educators, administrators and coordinators of language education programs in the U.S. participated in this study. Thematic analysis of the interview data indicated that all participants from different stakeholder groups were ideologically aligned with the pluralist views. The budget cuts were perceived as representative of broader assimilationist ideology. The negative impacts of eliminations on teacher professional development programs, K-12 public education, post-secondary language education, and world language education in America were expressed by the participants. The participants' counter arguments to the proposed budget eliminations are presented. This study has implications for the language education community, language policy makers, and educational policy planners in the U.S.
\end{abstract}

Keywords: Language ideologies, language policies, fiscal policies 
Başok, E., Sayer, P., Language Ideologies, Language Policies and their Translation into Fiscal Policies in the U.S. Perspectives of Language Education Community Stakeholders

\section{Introduction}

Policymakers enact language ideologies by promoting and implementing particular language policies. Language ideologies and language policies are two interconnected concepts with "complex, multiple, and often not straightforward" relation (Farr \& Song, 2011, p. 654). In this study, we will examine the link between two main ideological positions in the U.S. with regards to language in schools, pluralism and assimilationism, and the language education policies endorsed by proponents of each position. The impetus and focal point of the discussion is a major budget proposal by the current Trump administration to eliminate language education programs for the 2021 fiscal year. We include the viewpoints of stakeholders at various levels - administrators, program coordinators, and classroom language teachers - who would be impacted by the budget proposal.

Language ideologies are shared beliefs about specific languages, and by extension of the speakers of those languages (Tollefson, 2006). They are largely unconscious and often become naturalized, so that they become the ingrained and taken-for-granted assumptions about languages, including prestige (which languages are valuable) and hierarchies (the relative value of a language vis-à-vis other languages). Spolsky and Shohamy (2000) extend the idea of language ideologies from beliefs to include the actions taken to further these beliefs: "[language ideologies are] the beliefs about language and language use, and any specific efforts to modify or influence that practice by formulation of specific language policies" (p. 2). Similarly, Johnson (2013) notes that language policies can emerge from language ideologies as an explicit formulation of a structured belief system, or likewise policies can be interpreted and appropriated based on language ideologies. Since language policies impact many stakeholders and they are the byproducts of language ideologies of the power mechanisms, language policy is "an inherently political matter" (Grin, 2006, p.89).

However, language policies are less about language per se, and more a reflection of the ideological stance of the policymakers towards the speakers of particular languages. In the U.S., language policies include a gamut of measures mostly tailored to accommodating non-English speakers, such as translators for medical or court settings and access to services in government offices. Here, we limit our discussion to language education policies mostly in the form of programs specifically designed for English language learners such as dual language ${ }^{1}$, English as a second language (ESL), as well as programs designed for English speakers to promote multilingualism (called foreign or world language programs). While educational activities of all three types of programs would be significantly impacted by the proposed budget cuts, we are most concerned with the programs aimed at helping English learner $^{2}$ (EL) children of immigrant families achieve academic success. In the U.S., the

\footnotetext{
${ }^{1}$ Many people use the term dual language to refer to programs that have a balance of native English speakers and native speakers of the partner language. This model is also called two-way immersion or two-way bilingual immersion (Center for Applied Linguistics, n.d). The development of bilingualism (the ability to speak fluently in two languages), biliteracy (the ability to read and write in two languages), academic achievement (equal to that of students in nondual language bilingual programs), and cross-cultural competence are the goals of dual language programs (Gándara \& Escamilla, 2017, p. 6).

${ }^{2}$ We use the common term English Learners (ELs) to refer to students who have been assessed as less than fully proficient in English, and thus qualify for some form of English as a second language school services. The terminology varies in the U.S., and other terms such as English language learners (ELLS), English as New Language (ENL), or emergent bilinguals (EBs). While
} 
sentiment towards these programs has "shifted between tolerance and repression depending on politics, economy, and the size of the immigrant population" (Gándara \& Escamilla, 2017, p. 4).

For the Fiscal Year 2021 budget request, the Trump administration has proposed eliminating funding for several language education-related programs. The proposed budget includes the elimination of Title II of Every Student Succeeds Act (ESSA), Title IV, Part A of ESSA, English Language Acquisition, Title II of the Higher Education Act (HEA), and Title $\mathrm{VI} /$ Fulbright-Hays programs. The total targeted reduction equals $\$ 4.2$ billion (ACTFL, 2020). These programs fund teacher professional development programs, grants for students' academic achievement, world language instruction programs, English language acquisition programs, teacher quality partnership programs for colleges of education, international teaching, research programs, and curriculum development programs for K-12 postsecondary and graduate levels (ACTFL, 2020). While more than 10\% of American students in public schools are classified as English learners (ELS) (NCES, 2019), the amount of funding allocated to this fastest-growing body of students in the U.S. public education constitutes a minute portion of the federal education budget (Sugarman, 2016).

According to a recent statistical report presented by the U.S. Department of Education, from 2000 to 2016 the number of English learners (ELs) increased from 3.8 million to 4.9 million students in U.S. public schools, and in some of the states the percentage of ELs reached to 21.0 percent of overall school populations (NCES, 2019). We argue that, considering the increasing numbers of ELs, programs that directly or indirectly serve this growing student population hold great importance to ensure educational equity in America. However, teachers of ELs who need adequate training and continuous professional support to serve the growing EL population are more likely to report that they lack adequate school facilities, resources, and educational materials more than other teachers (Gandara \& Hopkins, 2010). To uncover the perspectives of those who would be directly or indirectly impacted by the proposed elimination of funding, we conducted in-depth interviews with different stakeholders. This study is guided by the following research questions:

1. How would the proposed budget cuts, and the current administration's language education policy, impact language educators?

2. How have language educators responded to the current administration's language education policy?

An analysis of the stakeholders' reactions to the proposed cuts for FY2021 reveals how language education professionals view the ideological ramifications of the budget. We begin by contextualizing language education policies within the broader assimilationist versus pluralist views and previous efforts to discourage the use of immigrant languages in the U.S., and then consider the views of the stakeholders.

\section{Assimilationist and Pluralist Language Ideologies in the U.S.}

The conflicting ideologies of assimilationists and pluralists have shaped language policies in the U.S. for many years. Assimilationists hold that rather than retaining their

ELs (with the notable exception of those from American Indian/Native Hawaiian groups) may be born abroad or in the U.S., all are children of immigrant families. 
languages, immigrants should learn English as soon as possible and assimilate into the U.S. culture, for two reasons: (1) for the immigrant themselves to be successful and (2) to preserve national unity and by adopting a common language. Within the assimilationist position is a strong language ideology of "one nation, one language," that equates linguistic unity of the nation-state with stability and harmony (Liddicoat, 2018). Assimilationists therefore support language policies that limits bilingual education ${ }^{3}$, as well as other language accommodation measures such as bilingual ballots. As a result, they encourage both language and cultural assimilation to become "true" Americans by making English their primary language (Schmidt, 2006). Language ideologies of assimilationists have translated into language policies with the support of advocacy groups and politicians who share assimilationist language ideologies. Using an argument of "educational equity", assimilationists argue that bilingual education should be replaced by programs, such as Structured English Immersion, aimed at quickly transitioning immigrant children into mainstream English classrooms (Ricento, 2006).

On the other hand, pluralists claim that language policies that promote both cultural and linguistic assimilation of immigrants will result in greater inequality for minority groups (Schmidt, 2006). Pluralists generally see linguistic diversity as a positive aspect of cultural pluralism, and therefore support bilingual education programs. Whereas assimilationists often argue that since immigrants come to this country by choice, they need to learn English to benefit from the opportunities that the U.S. can provide, pluralists argue that America has always been a multicultural and multilingual society and the ethnolinguistic diversity of its citizens must be valued and taken into account to provide social and educational equity for immigrants (Schmidt, 2006).

The differences in language ideologies of assimilationists and pluralists and their interpretation of these ideologies are outlined in Table 1.

Table 1: Assimilationist vs Pluralist Language Ideologies

Assimilationist

Pluralist

\begin{tabular}{|l|l|l|l|}
\hline Language Ideology & Interpretation & Language Ideology & Interpretation \\
\hline $\begin{array}{l}\text { English language as } \\
\text { more important }\end{array}$ & $\begin{array}{l}\text { Everyone needs to } \\
\text { learn English. English } \\
\text { is necessary for } \\
\text { getting a job or } \\
\text { accruing economic or } \\
\text { social capital }\end{array}$ & $\begin{array}{l}\text { Language as } \\
\text { endowments/additive } \\
\text { language ideology }\end{array}$ & $\begin{array}{l}\text { Bilingualism is } \\
\text { beneficial. People } \\
\text { should learn more } \\
\text { than one language. } \\
\text { More than one } \\
\text { language should be } \\
\text { promoted in schools. }\end{array}$ \\
\hline $\begin{array}{l}\text { ldeology of one } \\
\text { country/one } \\
\text { language }\end{array}$ & $\begin{array}{l}\text { The United States } \\
\text { should have an } \\
\text { official language. }\end{array}$ & $\begin{array}{l}\text { Language variation as } \\
\text { functional }\end{array}$ & $\begin{array}{l}\text { Language variation } \\
\text { serves a purpose. } \\
\text { Language variation }\end{array}$ \\
\hline
\end{tabular}

\footnotetext{
${ }^{3}$ Bilingual education is the use of two languages in the instruction and assessment of learners (Garcia, 2009). States have different regulations in place regarding bilingual education in the U.S. The vast majority of bilingual education programs are labeled as Transitional Bilingual Education (TBE programs are designed for students who are labeled as Els) where the ultimate goal is English acquisition. In this article we use bilingual education to refer to dual language bilingual programs such as two-way immersion programs.
} 


\begin{tabular}{|l|l|l|l|}
\hline & $\begin{array}{l}\text { Language has a } \\
\text { symbolic function in } \\
\text { society. The } \\
\text { dominant language } \\
\text { symbolizes a majority } \\
\text { national group. }\end{array}$ & $\begin{array}{l}\text { can facilitate } \\
\text { communication. } \\
\text { Using both languages } \\
\text { can assist students. }\end{array}$ \\
\hline $\begin{array}{l}\text { Transitional language } \\
\text { ideology }\end{array}$ & $\begin{array}{l}\text { Students in schools } \\
\text { need to transition to } \\
\text { English. English } \\
\text { acquisition is } \\
\text { prioritized over } \\
\text { bilingual acquisition. }\end{array}$ & $\begin{array}{l}\text { Language as a social } \\
\text { justice issue }\end{array}$ & $\begin{array}{l}\text { Access to language } \\
\text { affords access to } \\
\text { privilege and } \\
\text { opportunity }\end{array}$ \\
\hline
\end{tabular}

(Adapted with permission from Henderson, 2017)

\section{Pluralist ideologies: Advocates for bi- and multilingualism}

The two ideological positions on multilingualism are well represented in language education policy by bills that have been introduced by Republican and Democratic lawmakers, respectively. However, Farr and Song (2011) point out that the political reality is more complex; while pluralingualism can be observed at societal levels with the increasing numbers of immigrants, monoglot language ideologies are shared widely by both liberals and conservatives across the political spectrum. García and Kleyn (2016) argue that, even before the Trump administration took office, "as the U.S. population has become more linguistically diverse, language education policy has become more restrictive and increasingly guarded by the federal government" (p. 181). Nevertheless, we note that there are several programs that have been implemented in the U.S. to encourage bilingualism and multilingualism as part of pluralist ideologies. These programs honor the linguistic diversity in the U.S. and aim to provide an equitable education for minority groups. Some of the initiatives that encourage multilingualism in the U.S. education system that have emerged from the pluralist ideologies are the Seal of Biliteracy (SoBL), dual language programs, National Professional Development (NPD) grants for EL teachers, Advanced Placement (AP) and International Baccalaureate (IB) world language programs, and Fulbright-Hays programs. Some of the bills that were introduced by the U.S. lawmakers aligning with the pluralists ideologies include: Excellence and Innovation in Language Learning Act (2011) to improve foreign language instruction in the U.S., Advancing International and Foreign Language Education Act (2019) to support international and foreign language education research, and Biliteracy Education Seal and Teaching Act (2019) to establish and improve the seal of biliteracy programs to recognize bilingual students' language abilities in both English and a second language.

\section{Assimilationist Ideologies: English-only Advocacy Groups}

English-only advocacy groups in the U.S. have long sought to promote monolingual policies that support an assimilationist ideology. The policies promoted by English advocacy groups, such as eliminating bilingual education, prohibiting the use of languages other than English in government, and limiting the language services for non-English speakers are informed by assimilationist ideologies (Lawton, 2008). For the past decade, there have been 
many attempts (most of which were successful) to restrict bilingual education, bilingual voting ballots, and restrict bilingual services in the public sector in America (Ricento, 2013). The portrayal of immigrants as threats to the economy, law, and order, and bilingualism as a threat to national unity along with monolingual ideologies such as America First and Englishonly have long been promoted by two major English advocacy groups: U.S. English and ProEnglish. The arguments of U.S. English and avid supporters of other English-only proponents are a result of "false ideological beliefs about immigration and revolve around politics, economics, power and the fear of other" (Lillie \& Moore, 2014, p.3). While English only advocacy groups seem to advocate for linguistic nationalism by making English the official language of the U.S., according to Crawford (2001) the main motivation behind the English only movement ${ }^{4}$ is "discrimination and disenfranchisement" (cited in Lawton, 2016, p. 106).

The alt-right media in the U.S., along with English advocacy groups, play a major role in creating false beliefs about immigration, bilingual education, and multiculturalism. While the current unwelcoming atmosphere toward immigrants, bilingualism, and multiculturalism have seen a major rise during the past couple of years, the alt-right media has been fueling the fear of others in America for some time. For instance, one of the conservative media outlets in the U.S., Human Events, used the headline "1,400 English girls were raped by multiculturalism" (Prager, 2014) when they reported a vicious crime that took place in the U.K. The right-wing media has also shown its opposition to bilingual education in U.S. public schools repeatedly over the years. The same news organization, in another article, stated that "Bilingual education, known as language apartheid, discourages assimilation by keeping children with Hispanic-sounding names for years in Spanish-language public school classes" (Schlafly, 2008, para. 16). While these negative views toward bilingualism and multiculturalism have existed in America, the anti-immigration, anti-bilingualism, and antimulticulturalism rhetoric has increased dramatically over the past couple of years. More recently, an alt-right media outlet, Breitbart, shared their concerns regarding the Deferred Action for Childhood Arrivals (DACA) by stating "Amnesty for illegal aliens put America's most sacred and shared common tradition at risk: American English" (Binder, 2017, para. 1). Apart from inciting fear toward multiculturalism and bilingualism, the right-wing media also portrays immigrants as threats to the U.S. economy, even though research refutes these false claims (Frazee, 2018). However, the anti-immigrant, America First rhetoric used by politicians, the English-only discourse supported by advocacy groups, and the recent anti-immigrant discourse on several media outlets, play a big role in shaping the public perception regarding immigration, bilingualism, and multiculturalism.

Amongst the assimilationist-oriented advocacy groups, the groups U.S. English and ProEnglish have had a tremendous influence on lawmakers. Between 1984-1990 they succeeded in getting 13 states to declare English as their official language. Since the 1990s, the English-only movement has gained more political and financial support. In 2017, the year after Trump took office, ProEnglish alone raised over $\$ 2$ million in private contributions (ProEnglish Financial Statement, 2017). As of 2020, although the U.S. still has no official

\footnotetext{
4 US English, English First, and Pro-English are three organized advocacy groups that constitute the English-Only movement at the national level (Lawton, 2016, p. 106).
} 
language at the federal level, with the advocacy of the English only movement, 32 states have declared English as their official language ${ }^{5}$ (U.S. English, n.d).

Besides official English laws, the other main target of these groups have been bilingual education programs. One of the prominent supporters of the English-only movement in the U.S. is businessman Ron Unz who used the voter initiative process in California, Arizona, Colorado, and Massachusetts to spearhead anti-bilingual education bills. The Unz supported English-only groups successfully passed Proposition 227 (also known as the "English for the Children") in California in 1998 with the support of majority voters (Lillie \& Moore, 2014). A similar voter initiative in Arizona in 2000, Proposition 203, and Question 2 in Massachusetts in 2002, effectively eliminated bilingual education in all three states (Lillie \& Moore, 2014).

The stated goals behind these bills were to ensure bilingual students to achieve academic success as their English-speaking peers, prevent high dropout rates among bilingual students, and provide them with equal opportunities after graduation. However, research indicates that opposite occurred: English assimilation programs in these states exacerbated existing inequities for language minority students and had "detrimental effects on the academic success of ELLs" (Endo \& Reece-Miller, 2010, p. 91). For instance, four years after the implementation of Question $2^{6}$ in Massachusetts, Uriarte, et. al. (2010) found that dropout rates had not improved, and it further generated educational inequity for bilinguals by placing them in special education programs. Recent research (MacSwan et al., 2017) also found while English-only and English focused programs are not predictive of academic achievement for ELs, bilingual education contributes to their academic success at school by providing content-area knowledge in ELs' first language that enables them to keep up academically while learning English. In 2014, California voters rebuked the failure of Proposition 227 to improve educational achievement for ELs and passed Proposition 58 by a wide margin. This ballot initiative essentially reserved the 1998 decision and "authorized school districts to establish dual language immersion programs for both native and non-native speakers" (California Proposition 58, 2016).

In the U.S., both pluralists and assimilationists have received support from the politicians who align themselves with the language ideologies of these groups. The ideological conflict between these two groups in terms of language rights and equity for non-English speaking immigrants has resulted in bills and amendment conflicts in the U.S. Congress. Since 1981, the Republican Party with the support of English advocacy groups has led six initiatives that demanded English to become the official language of the United States and eliminate bilingual education along with bilingual ballots (Matos, 2018). Democrats, on the other hand, have sponsored bills that aim to create high-quality dual language immersion programs (SYLLABLE Act, 2020) and recognize bilinguals' proficiency in both English and a second language (Biliteracy Education Seal and Teaching Act, 2019) based on pluralist language ideologies.

\footnotetext{
${ }^{5}$ Although three states, Alaska, Hawaii and South Dakota, also recognize an indigenous language(s) as co-official.

${ }^{6}$ Question 2 replaced a wide-ranging set of bilingual programs with Structured English immersion (SEI), an instructional model that has as its main purpose the expedited learning of English (Uriarte, et. al. 2010, p. 65).
} 
Başok, E., Sayer, P., Language Ideologies, Language Policies and their Translation into Fiscal Policies in the U.S. Perspectives of Language Education Community Stakeholders

\section{Methodology}

To uncover the perspectives of those who could directly or indirectly be impacted by the proposed elimination of funding, this study employed a qualitative methodology. Semistructured in-depth interviews were conducted with six different stakeholders. Semistructured in-depth interviews involve researchers asking questions to interviewees who have expertise on the topics that the researcher is interested in with the goal of extracting as much information as possible by using follow-up questions (Morris, 2015). Since the researchers' goal in this study was to explore the perspectives of different stakeholders who might directly or indirectly be affected by the proposed budget eliminations by the current U.S. administration, semi-structured in-depth interviews granted the flexibility to the interviewees to openly divulge their perspectives. In-depth interviews provided the researchers with rich data fairly quickly by creating a space for the interviewees to share their insights and perspectives on the research topic (Morris, 2015). Semi-structured in-depth interviews were conducted to collect for data this study over Zoom with each interview lasting approximately 30-45 minutes. Online interviews enabled the researchers to overcome the geographical dispersion, financial, and time constraints in this study when compared to face to face interviews (Janghorban et al., 2014). Online interviews also proved to be viable alternatives to face to face interviews during the time of a global pandemic by enabling researchers to choose from varied communication options and to directly talk to the research participants anywhere, at any time (Salmons, 2014).

\section{Participants}

Based on the purposes of this study, and our goal to gather rich and unique data (Etikan et. al, 2016), we selected individuals through purposive sampling from three stakeholder groups within the language education community. Since this study aimed to explore the perspectives of stakeholders who would be directly or indirectly affected by the proposed budget eliminations, we deliberately selected participants based on their expertise in the language education community. The participants included two administrators, two world language program coordinators, and two world language teachers from the Midwestern U.S., representing programs in the areas of bilingual/dual language education, ESL, and world/foreign languages. The administrators were professionals (one in higher education, one in a state Department of Education) who had written and directed programs funded through federal grants and were familiar with the federal funding process. The second stakeholder group was comprised of coordinators of world language programs who were directly involved in the professional development of world language and English as a second language (ESL) teachers in their certification processes. Additionally, these stakeholders had been involved as participants in grant- funded programs such as Fulbright Hays. The final stakeholder group that was interviewed in this study was made up of world language teachers who could be affected by the proposed elimination of budget in their teaching. 
Başok, E., Sayer, P., Language Ideologies, Language Policies and their Translation into Fiscal Policies in the U.S. Perspectives of Language Education Community Stakeholders

Table 2: Participants (all names are pseudonyms)

$\begin{array}{lll}\begin{array}{l}\text { Name } \\ \text { Michael }\end{array} & \begin{array}{l}\text { Position } \\ \text { Language teacher trainer, } \\ \text { administrator }\end{array} & \begin{array}{l}\text { Area } \\ \text { TESOL/ESL }\end{array} \\ \text { Rachel } & \begin{array}{l}\text { State language program } \\ \text { administrator } \\ \text { Language education program } \\ \text { coordinator } \\ \text { Sam }\end{array} & \begin{array}{l}\text { World languages/Dual } \\ \text { language programs } \\ \text { TESOL/ESL/World languages }\end{array} \\ \text { Emma } & \begin{array}{l}\text { Coordinator } \\ \text { Spanish immersion teacher in }\end{array} & \text { Bilingual/Dual language } \\ & \text { A two-way dual language } & \\ \text { program } & \text { World languages } \\ \text { Tamara } & \text { High school Spanish teacher } & \text { World languages }\end{array}$

\section{Data Analysis}

The six transcribed interviews provided forty pages of data. Open coding (Emerson, Fretz \& Shaw, 2011) was employed to identify themes that were relevant to the research questions throughout the data set. Open coding enabled the researchers to categorize similar data units to easily find the cluster segments relating to particular research questions or themes (Miles, Huberman, \& Saldaña, 2019). The coding process also allowed the researchers to condense the data to be able to retrieve the most meaningful and relevant material to answer the research questions in this study (Miles, Huberman, \& Saldaña, 2019). Interview data were coded employing "first cycle coding" (Miles, Huberman, \& Saldaña, 2019) including descriptive, in-vivo, and concept coding. Data was coded by the first author and was checked by the second author of this study. Once the interview data was coded using first cycle codes, broad categories and labels were created which enabled the researchers to detect the patterns and themes related to the purposes of this study. The emergent themes were then analyzed using thematic analysis (Braun \& Clarke, 2006) to answer the two research questions that guided this study. To establish the credibility of the interview data, member checking (Creswell \& Miller, 2000) was conducted with the participants where the interview transcripts were verified by the interviewees to ensure the accuracy of the content in the transcripts.

\section{Findings and Discussion}

The goal of this study was to uncover the perspectives of six different stakeholders in the language education community regarding the impact of the current administrations' proposed budget cuts on language education programs in the U.S. Inspired by ACTFL'S statement (Appendix 1) on the proposed budget eliminations for the fiscal year 2021, the researchers aimed to answer the following research questions by conducting semi-structured interviews with the participants:

1. How have the members of the language education community responded to the administration's budget proposal and language education policy? 
Başok, E., Sayer, P., Language Ideologies, Language Policies and their Translation into Fiscal Policies in the U.S. Perspectives of Language Education Community Stakeholders

2. How would the proposed budget cuts, and the current administration's language education policy, impact language educators?

The themes that emerged after analyzing the interview data are presented below:

- Budget eliminations as representative of a broader assimilationist ideology

- The negative impact of eliminations on teacher professional development, intercultural competence, and educational equity

- Benefits of pluralist views on the language education community in the U.S.

All participants expressed pluralist views in terms of language ideologies. When the participants were asked about their perspectives on the proposed budget eliminations regarding the language education community in the U.S. some of the words that they used to show their reaction to the budget eliminations were "staggering", "a sense of myopia", "violence toward language", and "attack on education". The following section highlights the first overarching theme that emerged from the participants' interviews.

\section{Budget Eliminations as Representative of a Lack of Interest in Foreign Language Education and Broader Assimilationist Ideology}

To answer the first research question in this study, all participants were asked to reflect on the proposed budget eliminations by the current administration detailed by ACTFL (Appendix 1) and explain how, if approved, these eliminations would impact their jobs. When asked about her perspective on the proposed language education related budget eliminations, Elena, a middle school Spanish dual immersion teacher responded:

I think it is very easy to attack foreign language education. It is not something that is going to be a front-burner for most people. I believe that there is definitely a correlation between several different paths or avenues that they are [the administration] taking in regard to how they see their role in the world. In their proposal several of the things are conflicting. So, for example, they are cutting [funding] for ESL services, but they are promoting an agenda, which is English only. (Elena, Spanish immersion teacher)

Elena perceived the proposed budget elimination for the ESL services as conflicting with the overall English-only policy and transitional language ideologies (Henderson, 2017) that the current administration has been ideologically in favor of. According to English-only policies and transitional language ideologies as part of the assimilationist view, instruction should only be in English for ELs for them to better assimilate into the U.S. education system and society. As Elena pointed out above, accomplishing English only policies requires funding for ESL programs to serve the needs of the growing number of ELL population in the U.S. However, the administration proposed to eliminate $\$ 787$ million in funding for English Language Acquisition programs for the fiscal year 2021. Similar to Elena's position, when asked about his perspective on the budget proposal, Michael, a university language teacher education program director, responded:

This government has the belief that English is all that matters. When it comes to language, they buy into the assimilationist paradigm. The elimination of teacher development grants and the elimination of student academic achievement grants at the state level for world language instruction are physical manifestations of broader assimilationist ideology. (Michael, Administrator) 
When asked about her perspective on the budget proposal, Rachel, one of the administrator participants in this study responded:

Quite honestly, I think it signifies a lack of interest in foreign language education or any understanding of the importance that foreign language education plays in across many aspects of our society, government, and business, our economy, national security. By making this type of major across the board cuts signals a lack of comprehension about the importance that world language education plays in the overall scheme of American society. (Rachel, administrator)

The proposed budget by the administration eliminates $\$ 1.2$ billion current Title IV, Part A of ESSA, which funds student academic achievement grants and world language instruction programs (ACTFL, 2020). As an administrator in the state Department of Education working with world language program coordinators and dual language programs, Rachel pointed out that the proposed budget reflects the disinterest of the administration in world language education. Similar to what Michael stated, Rachel perceived eliminating world language education funding as representative of the broader English only belief system. However, as Elena pointed out it is also noteworthy that the proposed budget also eliminates the English language acquisition funding for ELs which contradicts the broader English-only agenda of the administration.

One of the world language program coordinators, Sam, pointed the shift in language ideologies in the U.S. and how this shift is represented in language policy documents by asserting:

The Office of English Language Acquisition used to be called the Office of English Language Acquisition and Bilingual Education 7 . There was a bilingual component or an acknowledgment of bilingualism in the conversations or in the laws or even in the judicial decisions. There seems to have been a move away from the inclusion of bilingualism as a term or as a method or as a vehicle for language teaching and language learning and more toward English language acquisition. Well, now bilingualism seems to be not even on the table (Sam, world language coordinator). As Sam revealed, the broader language ideologies of the administrations are reflected in the policy documents or even in the official titles of programs. The shift in the change of program names or the emphasis of language policies that Sam pointed out haven't started with this current administration, but with a larger reauthorization of the ESEA measure also known as No Child Left Behind (NCLB) in 2002. The reauthorization of the 1994 version of the Bilingual Education Act which aimed to develop ELs' English skills while developing their native language skills was completely reversed with NCLB which emphasized improving only English skills (Garcia \& Michie, 2005). In parallel with Sam's statement about "now bilingualism seems to be not even on the table", Garcia and Michie (2005) state that with the 2002 reauthorization of the Bilingual Education Act, "the word bilingual has been completely eliminated from the law" (p. 98). These policy changes have shaped the understanding of bilingual education in the U.S. As a result, the bilingual education programs in the U.S., as opposed to the rest of the world, have primarily focused on teaching English by adopting

\footnotetext{
7 It was actually established in 1974 as the Office of Bilingual Education and Minority Languages Affairs (OBEMLA) and reorganized in 2001 by the Bush43 administration as the Office of English Language Acquisition as part of the NCLB reform.
} 
transitional bilingual programs where the goal is English acquisition rather than developing EL's bilingualism and biliteracy with dual language programs (Gándara \& Escamilla, 2017).

The current administration's language ideologies, policies, and fiscal priorities are a continuum of assimilationist ideologies that have shaped the language education in the U.S. for the past two decades that has started with the NCLB in 2002. The elimination of bilingualism from the law and the shift to English only policies have encouraged the English advocacy groups in the U.S. to strike at bilingual education programs. In line with both Elena's and Michael's remarks, Tamara, a high school Spanish teacher brought up the English-only advocacy groups that have been actively involved in the language policy debate in the U.S. After defining the proposed budget eliminations as "staggering" Tamara added: "The ground is fertile for the English-only movement to really come to the forefront, so it is [proposed budget] just sort of giving them credence" (Tamara, Spanish world language teacher).

Corroborating Tamara's statement, ProEnglish, one of the major English advocacy groups in the U.S., shared its excitement when the English Language Unity Act (2019) was introduced by Rep. Steve King (R-lowa) and co-sponsored by 27 other Republican lawmakers by stating:

Great news! The Official English bill (H.R. 997) has been introduced in the 116th Congress. If passed, H.R. 997 would declare English as the official language of the United States! This bill will save American taxpayers untold billions of dollars and encourage new arrivals to our country to learn English and assimilate into our culture. The fact is, we have never seen a greater opportunity to make English our official language than now. President Trump and Vice President Pence have both been outspoken supporters of English language policies. (ProEnglish Action Center, n.d) Besides promoting their ideologically motivated goal of making English the official language of the U.S., English advocacy groups expect minorities with different linguistic and cultural backgrounds to adapt to the "American way of life" by eschewing their cultural and linguistic heritage. These groups also oppose federal spending on language services such as translation or interpretation services at schools and hospitals that accommodate non-English speakers. They want the U.S. government to repeal the Executive order 13166 signed by President Clinton to accommodate the "persons with limited English proficiency" (Exec. Order No. 13166, 2000). In one of his interviews with Breitbart, the executive director of ProEnglish stated:

We've actually had five meetings at the White House in recent weeks and months with different aides to President Trump and Vice President Pence, and we have really urged them to sign a new executive order repealing Clinton's executive order. (Binder \& House, 2018)

Both of these quotes reveal that "the ground is fertile" for these advocacy groups during the current U.S. administration as Tamara stated in her interview. When asked about English advocacy groups in the U.S. and their ideological tendencies Michael responded, "they portray themselves as very patriotic" and elaborated further on their ideological alignment with the current U.S. administration by stating:

This English first concept or American first concept that Trump started with America first is tapping into a fear of the unknown, a fear of diversity, which is xenophobic, 
which feeds into a fear of language because you can't divorce language from people's culture and from people's identities. To come to America, you need to speak English, drop your language, drop your culture, drop your religion (Michael, administrator).

As the participants stated in their interviews, the budget elimination request for the language education community by the current administration is perceived as a manifestation of the broader assimilationist ideology. The participants also addressed the America-first rhetoric that has become popular for the past couple of years in the U.S. political discourse as feeding into the fear of the unknown and giving credence to the English advocacy groups. Furthermore, the participants addressed the ideological alignment between the English-only movement and the current administration which was also revealed by the statements of these advocacy groups.

\section{The Negative Impact of Budget Eliminations on Teacher Professional Development, Intercultural Competence, and Educational Equity}

The second research question in this study explored the possible impact that the proposed budget elimination would have if passed for the language education community. To answer this research question, all stakeholders were asked to express their perspectives on how their jobs would be affected by budget eliminations. Out of the six interviewees in this study, only two of the participants were classroom teachers, but the coordinators and the administrators worked very closely with classroom teachers which enabled them to highlight the multilayered impact of eliminations. In their budget request for the 2021 fiscal year, the Trump administration proposed to eliminate the current \$2.1billion budget for the Title II of Every Student Succeeds Act (ESSA). ESSA was signed by President Obama with a bipartisan measure which has reauthorized the Elementary and Secondary Education Act (ESEA) to ensure educational equity for all students (U.S. Department of Education, n.d). ESSA also provides vital funding to teacher development grants that provide crucial funding for teacher professional development in both K-12 and post-secondary levels (ACTFL Statement, 2020).

Another major resource for language teacher professional development that the proposed budget eliminates is the Title VI of the Higher Education Act (HEA) and FulbrightHays programs. Fulbright-Hays programs were started in 1961 and aim to improve international teaching practices while providing professional development opportunities for U.S. teachers (Braimah \& Jotia, 2013). Title VI/ Fulbright Hays as one of the largest and longest-standing federal programs has also played a crucial role in supporting research in language acquisition by training language teachers, experts and researchers, while enabling material development, including language tools and assessment materials in the U.S. (Brecht \& Rivers, 2000). All six participants in this study expressed their concerns over the elimination of Fulbright-Hays funding by sharing their experiences with the program and detailing the possible impact of Fulbright-Hays budget eliminations on the professional development and intercultural competence of language educators. When asked about the possible impacts of the proposed budget eliminations on language teachers Elena responded:

I am a Fulbright recipient. I have actually done a full year in Lima, Peru through Fulbright so I can definitely speak to the merits of that program. I think it would be really devastating for an area in education that has very little funding and very little professional development to lose such an area. As an immersion teacher, I believe in 
the importance of being part of a community. So being able to immerse yourself in a different culture in a different country is very, very critical. So that is obviously concerning. (Elena, Spanish immersion teacher)

As Elena highlighted, Fulbright Hays programs are critical not only for teacher professional development activities but also for intercultural competence of language educators in the U.S. Another language teacher, Tamara, shared similar concerns with Elena by stating:

Title VI Fulbright Hays, which are great fellowship programs would certainly impact me. That's a professional development opportunity that I consider every summer. And I know that is a blow really to the professional development of teachers because it enriches our teachers, but then it enriches our students when we bring in teachers from other countries that [Fulbright Hays budget elimination] could trickle down and impact the students. (Tamara, High school Spanish teacher)

As Tamara mentioned, Fulbright Hays programs offer great professional development opportunities for language teachers, and at the same time they enrich U.S. students' cultural understanding when they work with teachers from different countries. Michael, a Fulbright scholar and a faculty member who wrote grants to bring teachers from abroad to the U.S., reiterated the importance of international exchanges through Fulbright programs based on his experience asserting:

I am a Fulbright Scholar. I spent last summer in Uruguay as a Fulbright Scholar and it opened up so many doors for me. The elimination of Title VI/Fulbright Hays bothers me tremendously. Last February, I brought 27 teachers from Uruguay here. They stayed in homestays, they worked with teachers in the classrooms. It was a really amazing experience for them. It's called a teacher exchange under the Fulbright umbrella. This would directly affect me, my students, my agenda. (Michael, administrator)

Besides addressing the positive impact of Fulbright Hays programs on intercultural understanding, Michael also addressed another important purpose that these cultural exchanges serve in the world by stating:

When we look at the intercultural and international exchanges, It creates a deeper understanding of one another. If we want to make peace around the world if we want to make this world a more just, equitable, amicable place we need more money in the State Department with Title VI with Fulbright Hayes and with Fulbright in general. (Michael, administrator) When asked about the possible impacts of budget elimination regarding the Title $\mathrm{VI}$ of Higher Education Act (HEA) and Fulbright Hays programs, Sam addressed the financial burden that this would put on teachers by stating:

If the Fulbright Hayes was defunded universities such as ours would not be able to train teachers to work with students who are learning English as an additional language. We would not be able to mediate that. They would have to pay for it out of pocket because the English language acquisition funding in my experience has basically paid the tuition for in-service teachers to be trained or to go through professional development to develop their language teaching abilities. (Sam, coordinator) 
As expressed by the participants, Fulbright Hays programs are very important for language teacher professional development and intercultural competence. However, the funding that is allocated to Fulbright Hays programs has been in decline since 2011 in the U.S. The budget cuts that were implemented in FY2011 severely impacted the foreign language infrastructure in the country, namely teacher training programs. In the following years "Title VI and Fulbright-Hays have still not recovered from those reductions and have seen their capacity further eroded" (National Humanities Alliance, n.d.). While the participants in this study revealed the benefits of Title $\mathrm{VI}$ and Fulbright-Hays programs, there is an alarming downward trend in Title VI \& Fulbright Hays budget allocations since FY2010. The $\$ 110.3$ million Title VI funding in 2010 was appropriated to $\$ 68.1$ million in the 2020 fiscal year, and similarly the $\$ 15.6$ million Fulbright-Hays funding was cut by almost half and appropriated to \$8.1 million in 2020 (Gurwitz, 2020). Furthermore, the Trump administration's proposed budget for FY2021 eliminates funding for Title VI and FulbrightHays programs. Another crucial funding for teacher professional development that the proposed FY2021 budget eliminates are the Title II grants. Sam, one of the coordinators who closely works with pre-service language teachers as the coordinator of teacher certificate programs, addressed the importance of the Title II grants for teacher professional development by asserting:

If Title II were to disappear my sense is that they would have less opportunity to provide resources or other opportunities to pursue professional development on behalf of language education initiatives, whether it be world language or ESL. (Sam, coordinator)

Title II of the Every Student Succeeds Act (ESSA), provides grants that help support the funding of teacher professional programs, similar to Title $\mathrm{VI}$ of the Higher Education Act (HEA) and the administrations' proposal to eliminate the current $\$ 2.1$ billion funding would have a damaging impact on teacher professional development.

Our findings regarding the impacts of Fulbright Hays programs on teachers concur with the findings of previous research (Braimah \& Jotia, 2013; Walters et al., 2011) conducted on the impact of Fulbright Hays programs on teacher professional development. For instance, Braimah and Jotia's (2013) study found that teachers who participated in Fulbright Hays programs increased their knowledge base, teaching methodologies, and cultural awareness. Similarly, Walters et al. (2011) found that the international immersion experience during Fulbright Hays projects had positive impacts on teachers' intercultural competence. As the participants in this study revealed, and the recent research has shown, Fulbright Hays programs are very critical in providing much-needed professional development and intercultural competence for U.S. language teachers. However, the 36.9\% decline between 2010 and 2016 in combined funding $(\$ 195,437,000$ in 2010 to $\$ 123,250,000$ in 2016) for National Resource Centers, Foreign Language and Area Studies Fellowships, Title VI, and the Fulbright Hays Programs (Modern Language Association, 2018) and the proposed elimination of Title VI and Fulbright Hays funding by the current administration poses great risks for the professional development and intercultural competence of language educators in the U.S.

Apart from funding the professional development of language teachers, the funding that is allocated to the language education community ensures the educational equity in the U.S. The federal funding is most critical for schools serving students in low socioeconomic 
status (SES) school districts and eliminating the budget for public schools would incite educational inequality in America. One of the participants pointed out the negative impacts of budget elimination for students in lower SES school districts by stating:

Cutting the budget is going to affect disproportionately the lower socioeconomic students especially in urban settings or rural settings. It is hard enough to compete with students from private schools for scholarships for college and if you take away this budget to support language education, it is going to affect public schools. A lot of urban public schools are comprised of minorities and it is [budget elimination] very disturbing. (Emma, world language administrator)

As the participants expressed in their interviews, if the requested budget is approved, it would have major impacts on language teachers' professional development, intercultural competence, and these cuts could also negatively impact minorities in U.S. public schools.

\section{Negative Impact of Eliminations on World Language Education}

The governments' federal spending on language education programs such as world language instruction show the value that the government gives to foreign language education. As Brecht and Rivers (2000) state, supporting foreign language education with federal funding sends a very important message to citizens, public schools, and colleges that the government values language education and strives to train language teachers which also encourages language enrollments nationwide. To address the negative message that the "America First" rhetoric and "English only" policies send to her rural midwestern Spanish classroom Tamara stated:

I really think there is a clear lack of acceptance of foreign languages and cultures and I think it manifests itself in everyday interactions. I feel it from my students. I sense that in the classroom every day. You get the old standard I do not need this. I only need English. English is more important, everybody should just learn English. This is a waste of my time. (Tamara, Spanish teacher)

The political rhetoric of "America First" as Tamara stated, impacts the public sentiment, namely it demotivates students in learning foreign languages. This political rhetoric, as well as "English only" policies, has translated into the current administrations' consecutive budget elimination requests which sends a negative message to citizens including students in language classrooms across the country. In line with the concerns that Tamara shared regarding the demotivating impacts of assimilationist ideologies and political rhetoric, Elena pointed out the decline in enrollment in foreign language education programs in the U.S. by stating:

I think one of the things that we've already started seeing is just the sheer reduction in people going into foreign language education. Even in the 90s, you would have students having options like German, French, and Spanish, now it's basically French and Spanish. Now there's even a proposal to eliminate foreign languages as a college requirement. (Elena, Spanish immersion teacher)

Supporting Elena's claims, a recent report on total undergraduate and graduate-level foreign language enrollments reported a 9.2\% decline between 2013 and 2016, making it the second-largest decline since 1972, with the closures of 651 language programs in only three years (Modern Language Association, 2018). The foreign language enrollment numbers for K- 
12 levels in U.S. public schools are no more promising compared to higher education. The enrollment numbers of $\mathrm{K}-12$ students in foreign language programs have been declining over the years to account for only $20 \%$ of the total student population in the U.S. (American Councils for International Education, 2017). Conversely, 92\% of European students learn a foreign language during primary and secondary schooling (Devlin, 2018).

There are many factors at play causing this decline in enrollment and closures of foreign language programs in higher education. To point out one of the most important factors affecting the enrollment numbers for foreign language programs both in $\mathrm{K}-12$ and post-secondary levels Rachel maintained:

Given the extremely limited funding that is available to world language programs both at the K-12 level and post-secondary level this [proposed budget elimination] is very concerning to me. I think it would have a rather devastating effect on our already dwindling resources and dwindling enrollment numbers for programs. If these cuts were to go through that would represent a rather huge diminishment in the funds available to districts to support curricular areas like foreign languages. (Rachel, administrator)

As both classroom teachers and the world language administrator stakeholders pointed out the official language policies based on assimilationist ideologies, incite a lack of acceptance toward foreign languages, and the elimination of funding for language education programs send a discouraging message to the public. As a result, the trickle-down effect that Elena pointed out becomes indispensable in both world language and dual language immersion classrooms as it negatively impacts the enrollment and students' motivation in learning a new language.

As the participants in this study asserted, the assimilationist language ideologies and their translation into fiscal policies decreasing or eliminating funding for language education and political rhetoric such as "America First" and "English Only" are some of the reasons for the low foreign language enrollment in both K-12 schools and higher education programs in the U.S. Confirming Tamara's concerns regarding the negative message that the America first rhetoric sends to her rural language classroom, Endo and Reece-Miller (2010) assert that the linguistic privilege of standard American English fueled with English-only rhetoric is the reason for the declining interest in learning languages and the lack of public awareness for the importance of multilingualism and multiculturalism. Despite the concerning trend in low enrollment, declines in the funding for language education programs, and the current negative sentiments toward foreign language education in America fueled by "America First" and "English only" movements, a recent survey (Eliassen, 2020) has found that $60 \%$ of Americans support increased funding for language education programs.

\section{Stakeholders' Counterarguments to Budget Eliminations}

In addition to sharing their perspectives on the possible impacts of budget eliminations on the language education community, the participants in this study provided counterarguments to the administrations' budget eliminations. When asked about what she would tell the policymakers to reassess their proposed budget, Elena as an immigrant herself addressed the importance of dual language/two way immersion programs by stating: 
I grew up in Mexico, and I came to the United States. When I think about the program I am in as a teacher, if that had been available to me as a student, I would have had a very different experience in how I learned and how I work and how I even probably developed as a person. So not having had access to the world as accepting of who I am as a dual language speaker really was difficult. I think that for the students that do have that opportunity to go to a school like mine is really critical. (Elena, Spanish immersion teacher)

As a representative of pluralist ideologies, "dual language education programs provide academic content and language instruction in two languages to promote bilingualism and biliteracy, mastery of academic content, and cross-cultural awareness" (Boyle et al. 2015, p. 43). While they aim to develop high levels of proficiency for students in both languages, dual language programs also aim to develop an appreciation and understanding of different cultures that Elena did not have access to during her schooling in the U.S. As opposed to the assimilationist discourse in America that encourages both linguistic and cultural assimilation of immigrants for them to achieve high levels of academic proficiency, recent research (Gómez, 2013; Lindholm-Leary \& Block, 2010; Valentino \& Reardon, 2015) found that additive bilingual programs provide more academic achievement opportunities for ELs compared to other programs. In line with what Elena stated, regarding the importance of dual language programs like hers, Lindholm-Leary and Block's (2010) study found that Hispanic students who attend dual language programs in low SES schools achieve comparably or significantly higher than their Hispanic peers in mainstream classrooms in English reading, language arts and mathematics according to test scores. Similarly, Valentino and Reardon's (2015) study which compared the academic achievement of ELs in different instructional programs found that the English Language Arts (ELA) test scores of students in bilingual programs improved as fast as their peers in English immersion classrooms if not faster.

Besides their positive impact on students' academic achievement, dual language immersion programs also aim to maintain ELs' home languages, as opposed to their linguistic assimilation into English (Morales \& Aldana, 2010). The elimination of funding for these programs would greatly impact ELs' home language maintenance as Elena expressed:

I think all of these things trickle down to an immersion school where we are trying to promote students not only learning a new language but also retaining their own language as participants in our program. (Elena, Spanish immersion teacher) Another language teacher, Tamara, mentioned the valuable contributions that the bilingual and world language programs make to the society by stating:

I think you look at individual students and look at the contributions that they are making to the society, there are valuable things coming out of the foreign language classrooms. This [budget elimination] is concretely, impacting students to enrich their community. (Tamara, Spanish teacher)

Michael addressed the financial, and international benefits of bilingualism and multilingualism as a counterargument to the administration's request for budget eliminations by stating:

I would say if you put more money into the schools to pay for bilingualism and multilingualism our economy will boom. Because they will be more marketable. If we want to have fewer wars, fewer conflicts, fewer disagreements, and 
misunderstandings, we need to promote bilingualism at minimum multiculturalism.

(Michael, administrator)

Similarly, Rachel addressed the benefits of bilingualism and multilingualism regarding the economy, national security, and overall cultural prosperity in the country by stating:

I would provide them [administration officials] with research-based information that shows the very clear benefits of having a citizenry that is highly proficient in multiple languages and multiple cultures. How that benefits our economy, our national security, our overall cultural prosperity, and diversity in the country. (Rachel, administrator)

As the participants' counterarguments revealed, providing funding for bilingual education, especially dual language immersion programs, is critical since they enable students to maintain their home languages, enrich their community, and contribute to the overall diversity of America. Furthermore, as the participants expressed in their counterarguments funding dual language and world language education programs benefits the U.S. economy and national security.

\section{Implications and Conclusion}

This study explored the perspectives of six stakeholders in the language education community regarding the proposed budget eliminations of the Trump administration for FY2021. The debate around budget funding was framed through language education policies as reflecting language ideologies. In particular, we considered how assimilationist and pluralist ideologies are enacted through language policies. The findings showed that all participants were ideologically aligned with pluralist views and regarded the proposed eliminations of the Trump administration as representative of broader assimilationist language ideologies. Each participant detailed the possible impacts of proposed budget eliminations and how it would affect their roles as key stakeholders in the language education community. As all the participants stated, funding language education programs such as Title $\mathrm{VI} /$ Fulbright Hays grants are very crucial for teacher professional development and intercultural competence. This study found that the decreasing value given to foreign language education in America over the years based on assimilationist ideologies sends negative messages to students in schools. As the classroom teachers stated in this study, the political rhetoric fueled by assimilationist ideologies creates a trickle-down impact on students resulting in a lack of interest in learning languages. This study also found that eliminating almost $\$ 4$ billion in funding for the language education community as proposed by the Trump administration would impede the educational achievement gap for public school students.

The counterarguments voiced by participants have important implications for the current and future U.S. administrations regarding language policies and the vital role of federal funding for the language education community. Eliminating the much-needed funding for the language education community as proposed by the current U.S. administration for the fiscal year 2021 would have adverse effects on the American public on many levels. As the participants in this study have expressed, funding dual language, world language programs, and the language education community in general has a direct impact on the economic welfare, national security, educational equity, cultural diversity, and prosperity of America. 
These critical rationales for funding language education have been evidenced elsewhere (Brecht \& Rivers, 2000; Franks, 2019; Liddicoat, 2018).

While this study has presented the perspectives of six participants who are actively involved in the language education community in the U.S. as world language educators, dual language immersion teachers, coordinators and administrators, it is important to note its limitations. The perspectives of the stakeholders in this study are not generalizable to the entire language education community in the U.S. Further research is needed to understand the broader impacts of language polices and their translation into fiscal policies that directly or indirectly impact the fast-growing language education community in the U.S. Further research is also needed to explore the reasons for the decline in foreign language programs in the U.S., the impacts of Title VI/Fulbright Hays programs on teacher professional development, and intercultural competence.

We are aware that the budget proposals of the Trump administration are not final unless approved by congress, and the house appropriation committee has already appropriated the education budget for FY2021. While the FY2021 budget has still not been approved, the draft funding bill by the house appropriations committee provides crucial funding that the Trump administration proposed to eliminate. Some of these appropriations include \$2.2 billion for the Title II, \$797 million for English Language Acquisition, \$52 million for Teacher Quality Partnerships (House Committee for Appropriations, 2020), \$70 million for Title VI, and \$9.5 million for Fulbright Hays funding (Gurwitz, 2020). While the house appropriations committee passed these appropriations, the disagreements between the senate Republicans and Democrats halted the approval of the FY2021 budget. Currently, there is a resolution until December $11^{\text {th }}$ by when the results of the presidential and the congressional elections will be known, and possibly the completion of the appropriations process will be completed under a new administration (The Concord Coalition, n.d.).

As researchers we share ACTFL and other language education advocacy groups ${ }^{8}$ concerns and urge the decision-makers in fiscal policies in both the Trump administration and future U.S. administrations to consider the importance of funding for the ESL, dual/world language education and language teacher professional development in the U.S.

\footnotetext{
${ }^{8}$ ACTFL is one of the professional organizations along with TESOL and NABE that engage in advocacy for the language education community in the U.S. These organizations advocate for the betterment of the language education community in the U.S. including the ESL, world language education, language teacher development, and bilingual education.
} 


\section{References}

Advancing International and Foreign Language Education Act, H.R. 2562, $116^{\text {th }}$ Cong. (2019). https://www.congress.gov/bill/116th-congress/house-bill/2562/text

American Council on the Teaching of Foreign Languages (ACTFL). (2019, March 13). ACTFL Statement on Trump Administration's FY20 Budget Request. ACTFL. https://www.actfl.org/news/press-releases/actfl-statement-trumpadministrations-fy20-budget-request

American Council on the Teaching of Foreign Languages (ACTFL). (2020, February 13). ACTFL Statement on Trump Administration's FY21 Budget Request. ACTFL. https://www.actfl.org/news/press-releases/actfl-statement-trumpadministrations-fy21-budget-request

American Councils for International Education. (2017). The national foreign language enrollment survey report [June 2017]. Washington, DC: American Councils for International Education. Retrieved from https://www.americancouncils.org/sites/default/files/FLE-report-June17.pdf

Biliteracy Education Seal and Teaching Act, H.R. 3119, 116 ${ }^{\text {th }}$ Cong. (2019). https://www.congress.gov/bill/116th-congress/house-bill/3119

Binder, J., House, A. (2018, April 19). English Language Advocates Urge Trump to Repeal Executive Order Requiring Costly Translation Services. BREITBART. https://www.breitbart.com/politics/2018/04/19/english-language-advocates-urgetrump-to-repeal-executive-order-requiring-costly-translation-services/

Biraimah, K. L., \& Jotia, A. L. (2013). The longitudinal effects of study abroad programs on teachers' content knowledge and perspectives: Fulbright-Hays group projects abroad in Botswana and Southeast Asia. Journal of Studies in International Education, 17(4), 433-454.

Boyle, A., August, D., Tabaku, L., Cole, S., \& Simpson-Baird, A. (2015). Dual Language Education Programs: Current State Policies and Practices. Office of English Language Acquisition, US Department of Education.

Braun, V. \& Clarke, V. (2006). Using thematic analysis in psychology. Qualitative Research in Psychology, 3(2), 77-101. https://doi.org/10.1191/1478088706qp063oa

Brecht, R.D. and Rivers, W.P. (2000). Language and national security in the 21st century: The role of the Title VI/Fulbright-Hays in supporting national language capacity, KendallHunt Publishing Company.

California Proposition 58, Non-English Languages Allowed in Public Education (2016). https://ballotpedia.org/California_Proposition_58,_NonEnglish_Languages_Allowed_in_Public_Education_(2016)

Center for Applied Linguistics (n.d.). Two-Way Immersion. https://www.cal.org/twi/faq/faq19.htm\#: :text=

Crawford, J. (2001). A nation divided by one language. Guardian Unlimited. http://www.guardian.co.uk.

Creswell, J. W., \& Miller, D. L. (2000). Determining validity in qualitative inquiry. Theory into practice, 39(3), 124-130. 
Devlin, K. (2018, August 6). Most European students are learning a foreign language in school while Americans lag. Pew Research Center. https://www.pewresearch.org/facttank/2018/08/06/most-european-students-are-learning-a-foreign-language-in-schoolwhile-americans-lag/

Eliassen, I. (2020, August 24). Do Americans Support Funding for Foreign Language Education? International Policy Digest. https://intpolicydigest.org/2020/08/24/do-americanssupport-funding-for-foreign-language-education/

Emerson, R. M., Fretz, R. I., \& Shaw, L. L. (2011). Writing ethnographic fieldnotes (2nd ed.). University of Chicago Press.

English Language Unity Act, H.R. 997, 116 ${ }^{\text {th }}$ Cong. (2019). https://www.congress.gov/bill/116th-congress/house-bill/997?r=9\&s=1

Exec. Order No. 13166, 65 Fed. Reg. 159 (August 16, 2000).

Excellence and Innovation in Language Learning Act, H.R. 1994, 112 ${ }^{\text {th }}$ Cong. (2011). https://www.congress.gov/bill/112th-congress/house-bill/1994?s=1\&r=24

Etikan, I., Musa, S. A., \& Alkassim, R. S. (2016). Comparison of convenience sampling and purposive sampling. American journal of theoretical and applied statistics, 5(1), 1-4.

Farr, M., \& Song, J. (2011). Language ideologies and policies: Multilingualism and education. Language and Linguistics Compass, 5(9), 650-665.

Franks, S. (2019, March 4). America's failure to fund language education is creating a crisis. Language Line Solutions. https://blog.languageline.com/americas-failure-to-fundlanguage-education-is-creating-a-crisis

Frazee, G. (2018, November 2). 4 myths about how immigrants affect the U.S. economy. PBS News Hour. https://www.pbs.org/newshour/economy/making-sense/4-myths-abouthow-immigrants-affect-the-u-s-economy

Gándara, P., \& Escamilla, K. (2017). Bilingual education in the United States. Bilingual and multilingual education, 1-14.

Gándara, P., \& Hopkins, M. (2010). English learners and restrictive language policies. Teachers College Press.

García, O. (2011). Bilingual education in the 21st century: A global perspective. John Wiley \& Sons.

García, O., \& Kleyn, T. (Eds.). (2016). Translanguaging with multilingual students: Learning from classroom moments. Routledge.

Garcia, E. E., \& Michie, G. (2005). Teaching and learning in two languages: Bilingualism and schooling in the United States. ProQuest Ebook Central. https://ebookcentral-proquest-com.proxy.lib.ohio-state.edu

Gómez, D. S. (2013). Bridging the opportunity gap through dual language education. Doctoral Dissertation, California State University, Stanislaus. Retrieved from https://core.ac.uk/reader/48503940

Grin. F. (2006). Language Policy: Economic Consideration in Language Policy. In Ricento, T. (Ed.) (2006). An introduction to language policy: Theory and method. (pp. 95-110). Blackwell Publishing.

Gurwitz, B. (2020, July14). House Appropriations Bills Include Increases for the Humanities. National Humanities Alliance. 
https://www.nhalliance.org/house_appropriations_bills_include_increases_for the_humanities

Henderson, K. I. (2017). Teacher language ideologies mediating classroom-level language policy in the implementation of dual language bilingual education Elsevier. doi:10.1016/j.linged.2017.08.003

House Committee for Appropriations, (2020, July 7). Appropriations Subcommittee Approves Fiscal Year 2021 Labor-HHS-Education Funding Bill. https://appropriations.house.gov/news/press-releases/appropriations-subcommitteeapproves-fiscal-year-2021-labor-hhs-education

Janghorban, R., Roudsari, R. L., \& Taghipour, A. (2014). Skype interviewing: The new generation of online synchronous interview in qualitative research. International Journal of Qualitative Studies on Health and Well-being, 9(1), 24152.

https://doi.org/10.3402/qhw.v9.24152

Johnson, D. C. (2013). Language policy. Palgrave Macmillan.

Lawton, R. (2008, July). Language policy and ideology in the United States: A critical analysis of 'English Only'discourse. In Lancaster University Postgraduate Conference in Linguistics \& Language Teaching (Vol. 3, pp. 78-103).

Lawton, R. (2016). A critical integrated approach to language policy as discursive action: Strengths, challenges, and opportunities. In Discursive approaches to language policy (pp. 105-127). Palgrave Macmillan.

Liddicoat, A. J. (2018). 7 National security in language-in-education policy. In Un (intended) Language Planning in a Globalising World: Multiple Levels of Players at Work (pp. 113128). Sciendo Migration.

Lillie, K. E., \& Moore, S. C. K. (2014). SEl in Arizona: Bastion for states' rights. In S. C. K. Moore (Ed.), Language policy processes and consequences: Arizona case studies (pp. 1-27). Multilingual Matters.

Lindholm-Leary, K., \& Block, N. (2010). Achievement in predominately low SES/Hispanic dual language schools. International Journal of Bilingual Education and Bilingualism, 13(1), 43-60.

MacSwan, J., Thompson, M. S., Rolstad, K., McAlister, K., \& Lobo, G. (2017). Three theories of the effects of language education programs: An empirical evaluation of bilingual and English-only policies. Annual Review of Applied Linguistics, 37, 218-240.

Modern Language Association. (2018). Enrollments in Languages Other Than English in United States Institutions of Higher Education, Summer 2016 and Fall 2016: Preliminary Report.

Morales, P. Z., \& Aldana, U. S. (2010). Learning in two languages: Programs with political promise. In Gándara, P., \& Hopkins, M. (Eds.), English learners and restrictive language policies (pp. 159-174). Teachers College.

Miles, M. B., Huberman, A. M., \& Saldaña, J. (2013). Qualitative data analysis. SAGE Publications.

Morris, A. (2015). A practical introduction to in-depth interviewing. Sage. 
National Council for Education Statistics (NCES). (2019). The Condition of Education: English Language Learners in Public Schools. Retrieved from: https://nces.ed.gov/programs/coe/pdf/Indicator_CGF/coe_cgf_2019_05.pdf

ProEnglish. (2017). Financial Statements. https://proenglish.org/financial-statements/

ProEnglish. (n.d). Pro English Action Center. https://proenglish.org/proenglish-actioncenter/

Ricento, T. (2006). An introduction to language policy: Theory and method. Blackwell Publishing.

Ricento, T. (2013). Language policy, ideology, and attitudes in English-dominant countries. In The Oxford handbook of sociolinguistics. https://www.oxfordhandbooks.com/view/10.1093/oxfordhb/9780199744084.001.00 01/oxfordhb-9780199744084-e-26

Salmons, J. (2014). Qualitative online interviews: Strategies, design, and skills. Sage Publications.

Schmidt, R. (2006). Political theory and language policy. In Ricento, T. (Ed.) (2006). An introduction to language policy: Theory and method (pp. 95-110). Blackwell Publishing.

Shohamy, E., \& Spolsky, B. (2000). Language practice, language ideology, and language policy. Language policy and pedagogy: Essays in honour of A. Ronald Walton, 1-41.

Sugarman, J. (2016). Funding an equitable education for English learners in the United States. Washington DC: Migration Policy Institute, 1-50.

The Concord Coalition (n.d.). Fall shutdown. https://www.concordcoalition.org/fall-shutdown

Tollefson, J. (2006). Critical Theory in Language Policy. In Ricento, T. (Ed.) An Introduction to Language Policy Theory and Method (pp. 42-56). Blackwell Publishing.

Uriarte, M. Tung, R. Lavan, N. \& Diez, V. (2010). Impact of restrictive language policies on engagement and academic achievement of English learners in Boston public schools. In Gándara, P., \& Hopkins, M. (Eds.) Forbidden Language: English Learners and Restrictive Language Policies (pp. 65-85). Teachers College Press.

U.S. Department of Education (n.d.) Every Student Succeeds Act (ESSA). https://www.ed.gov/essa?src=rn

U.S. English (n.d.). Official English. https://www.usenglish.org/us-states-officialenglish-laws/

Valentino, R. A., \& Reardon, S. F. (2015). Effectiveness of Four Instructional Programs Designed to Serve English Learners: Variation by Ethnicity and Initial English Proficiency. Educational Evaluation and Policy Analysis, 37(4), 612-637. https://doi.org/10.3102/0162373715573310

Walters, L. M., Green, M. R., Wang, L., \& Walters, T. (2011). From heads to hearts: digital stories as reflection artifacts of teachers' international experience. Issues in Teacher Education, 20(2), 37-52. 
Wright, W. E., \& Baker, C. (2017). Key concepts in bilingual education. Bilingual and Multilingual Education. Encyclopedia of Language and Education. (3rd ed). Springer, 65-80. 
Appendix 1: ACTFL Statement on Trump Administration's FY21 Budget Request

FOR IMMEDIATE RELEASE

CONTACT: Howie Berman, MA, CAE

(703) 894-2900 ×106

Alexandria, VA (February 13, 2020)

On February 10, the Trump Administration released its budget request for FY2021, which eliminates dedicated federal funding for several major programs vital to the language education community, including but not limited to:

- Elimination of Title II of the Every Student Succeeds Act (ESSA), which helps fund teacher development grants at the state level that are then distributed to local agencies. The current funding level is $\$ 2,1 b$.

- Elimination of Title IV, Part A of ESSA, which funds student academic achievement grants at the state level, including those for improving access to world language instruction. The current funding level is $\$ 1.2 b$.

- English Language Acquisition - This program provides grants to states to support English language acquisition. The current funding level is $\$ 787 \mathrm{~m}$.

- Elimination of Title II of the Higher Education Act (HEA), which funds the Teacher Quality Partnership grant program for colleges of education. The current funding level is $\$ 50.1 \mathrm{~m}$.

- Elimination of Title VI/Fulbright-Hays, which funds grant and fellowship programs that strengthen language instruction, area/international studies teaching and research, professional development, and curriculum development at the K-12, postsecondary, and graduate levels. The current funding level is $\$ 76.1 \mathrm{~m}$.

ACTFL strongly opposes these cuts to the federal budget. "Instead of cutting these programs, we should be increasing their funding levels," said Howie Berman, ACTFL Executive Director. "The need for language skills is growing at a breakneck pace-in our workforce, in our military, in our national intelligence apparatus, and most importantly, in our classrooms. These cuts will leave our students unable to compete in a rapidly changing, $21^{\text {st }}$ century global economy."

ACTFL President Bridget Yaden added, "The language education profession is already facing incredible challenges with respect to teacher recruitment and retention, as more than 44 states and the District of Columbia currently report shortages of qualified language teachers. These cuts will only make it easier for those considering language teaching to choose another career path." 
ACTFL implores Congress to reject this short-sighted budget request. While we take nothing for granted, we are confident that our work on Capitol Hill, in conjunction with our many partners, will lead to passage of a budget that looks nothing like the President's version. In the coming weeks and months, Congress will embark on its own process to produce appropriations bills that will fund the government through FY2021. We implore U.S. lawmakers to fully fund these integral federal programs that benefit our nation's students and teachers, along with our national security and economic viability. 